\title{
Matematik Öğretmen Adaylarında Bilişsel Stil, Görsel Matematik Okuryazarlı̆̆ı Ve Matematik Başarısı İlişkisinin İncelenmesi: Simetri Örneği
}

Emre Durasi $^{1}$, Gülay Yalim ${ }^{2}$, Kübra Karadeniz $^{3}$, Ŏguz Yalçıntuğ ${ }^{4}$, Samet Şahiner $^{5}$, Sinem İnce $^{6}$, Yasin Çetin ${ }^{7}, Z_{\text {Zeynep Şahin }}^{8}$, Zülal Kenar $^{9}$, Dr. Öğr. Üyesi Özlem Çeziktürk ${ }^{10^{*}}$

Geliş tarihi: 10.09 .2019

Kabul tarihi: 07.10.2019

\section{Atıf bilgisi:}

IBAD Sosyal Bilimler Dergisi

Sayı: Özel Sayı Sayfa: 589-606

Yıl: 2019

This article was checked by Turnitin. Similarity Index $22 \%$.

1 Marmara University, Turkey, emredurasi@gmail.com ORCID ID 0000-0001-7045-6028

2 Marmara University, Turkey, gulayvalim@gmail.com

ORCID ID 0000-0001-7045-6028

3 Marmara University, Turkey, kubrakaradeniz44@gmail.com,

ORCID ID 0000-0001-6545-5397

4 Marmara University, Turkey, valcintug_01@hotmail.com

ORCID ID 0000-0001-7045-6028

5 Marmara University, Turkey, abdussemadsahiner@gmail.com ORCID ID 0000-0001-7045-6028

6 Marmara University, Turkey, sinem.yar@hotmail.com

ORCID ID 0000-0001-7045-6028

Marmara University, Turkey, ctnysn@gmail.com

ORCID ID 0000-0001-7045-6028

8 Marmara University, Turkey, zeynep.sahin@marmara.edu.tr

ORCID ID 0000-0001-7045-6028

Marmara University, Turkey, zlal 10@hotmail.com

ORCID ID 0000-0001-7045-6028

10 Marmara University, Turkey, ozlem.cezikturk@marmara.edu.tr, ORCID ID 0000-0001-7045-6028

\footnotetext{
* Sorumlu yazar
}

ÖZ

Matematik öğretmen adaylarının simetri konusundaki matematik başarı düzeyleri, görsel matematik okuryazarlık durumları ve bilişsel stilleri varsa olası ilişkiler için, simetri konusundaki kavram yanılgıları ve zorluklar konusunda ve aday öğretmenlerin niteliklerini açığa çıkararak incelenmiştir. Araştırma tasarımı olarak ilişkisel model kullanılmıștır. Örneklem ulaşılabilir örneklem yöntemiyle İstanbul'da bir devlet üniversitesinin 4. Sınıfinda okuyan 80 aday öğretmeni içermiştir. Aday öğretmenler GEFT (Gizlenmiş şekiller grup testi) ve Görsel okuryazarlık testleriyle ölçülmüştür. Matematik başarısı araștırmacılar tarafindan hazırlanılmış matematik başarı testiyle ölçülmüsstür. Simetri alan yazında fazla incelenmemiştir ve diğer konulardan daha fazla görsel içeriğe sahip olmasının yan sıra geometrik düşüncenin gelişiminde ve öğrencilerin görsel yöneliminin gelişiminde önemli role sahiptir. Öğretmenlerin bu konuya yeterince önem vermemesinin sebepleri arasında simetri konusundaki becerilerinin azlığı gelebilir. $\mathrm{Bu}$ üç değişken arasında çok güçlü bir ilişki bulunamamıştır. Simetri eksenini bulmada ve simetri tanımlarında kavram yanılgılarına sahip oldukları gözlemlenmiştir. Simetri konusunda alana bağımlı öğrenciler için bazı farklı analizler yapılabilir.

Anahtar Kelimeler: Bilişsel stil, alana bağlılık/bağımsızlık, görsel matematik okuryazarlığ 1 , simetri 


\title{
Cognitive Style, Visual Math Literacy and Mathematics Success of Preservice Mathematics Teachers: Symmetry Example
}

\author{
Emre Durasi $^{1}$, Gülay Yalim ${ }^{2}$, Kübra Karadeniz $^{3}$, Oğuz Yalçıntuğ $\breve{g}^{4}$, Samet Şahiner $^{5}$, Sinem İnce $^{6}$, \\ Yasin Çetin ${ }^{7}, Z_{\text {Zeynep Şahin }}^{8}$, Zülal Kenar ${ }^{9}$, Assist. Prof. Dr. Özlem Çeziktürk ${ }^{10^{*}}$
}

First received: 10.09.2019

Accepted: 07.10.2019

\section{Citation:}

IBAD Journal of Social Sciences

Issue: Special Issue Pages: 589-606

Year: 2019

This article was checked by Turnitin. Similarity Index $22 \%$.

1 Marmara University, Turkey, emredurasi@gmail.com

ORCID ID 0000-0001-7045-6028

2 Marmara University, Turkey, gulayyalim@gmail.com

ORCID ID 0000-0001-7045-6028

Marmara University, Turkey,

kubrakaradeniz44@gmail.com,

ORCID ID 0000-0001-6545-5397

4 Marmara University, Turkey, valcintug 01@hotmail.com

ORCID ID 0000-0001-7045-6028

Marmara University, Turkey,

abdussemadsahiner@gmail.com

ORCID ID 0000-0001-7045-6028

6 Marmara University, Turkey, sinem.var@hotmail.com

ORCID ID 0000-0001-7045-6028

7 Marmara University, Turkey, ctnysn@gmail.com

ORCID ID 0000-0001-7045-6028

Marmara University, Turkey, zeynep.sahin@marmara.edu.tr ORCID ID 0000-0001-7045-6028

9 Marmara University, Turkey, zlal 10@hotmail.com

ORCID ID 0000-0001-7045-6028

10 Marmara University, Turkey, ozlem.cezikturk@marmara.edu.tr,

ORCID ID 0000-0001-7045-6028

\footnotetext{
* Corresponding Author
}

\begin{abstract}
Mathematics teacher candidates' mathematical achievement scores on symmetry, visual mathematics literacy status and cognitive styles were investigated for possible relations, the misconceptions of concept and challenges on symmetry, qualities of prospective teachers to reveal the relationship, if exist. Correlational model was used as research design. Sample consisted 80 math teacher candidates who are studying in the 4th class in a state university in Istanbul and chosen by convenience sampling, where the researcher has identified the convenient group for study. Teacher candidates were tested with the GEFT (Confidential Shapes Group Test) and visual math literacy tests. Mathematical success is measured by the mathematics success test prepared by the researchers. Symmetry is not examined in the literature and it has more visual content than other subjects and plays important role in the development of geometric thinking and spatial orientation of the students. Among the reasons why the teachers don't give importance to this subject, that they don't have competence on symmetry. No significant relation between these three variables are found. They have some misconceptions as on finding the symmetry axis and on symmetry definitions. Some measures can be taken for field dependent students on symmetry as well.
\end{abstract}

Keywords: cognitive style, field dependent/independent, visual math literacy, symmetry 


\section{GíRiş}

İnsanları diğer canlılardan ve kendi türlerinden ayıran en belirgin özelliği, düşünme yeteneğidir (Alkan \& Güzel, 2005). Düşünebilme ve olaylardan anlam çıkarıp koşulları kendi lehine düzenleyebilme yeteneği yalnızca insanlarda görülür ve zamanla gelişir. Bunu sağlayan en önemli araçlardan biri matematiktir (Tural, 2005; aktaran Arslan \& Yıldız, 2010). Matematiksel düşünme, "matematiksel teknik, kavram ve yöntemleri problem çözme sürecinde dolaylı ya da doğrudan sistematik olarak kullanmak" şeklinde tanımlanabilir (Henderson, Marion, Fritz, Riedesel, Hamer, Scharf, et al. 2004; aktaran Arslan \& Yıldız, 2010).

Deney ve gözlem akıl yürütmeyle desteklendiğinde anlam kazanır. Tüm kuralların ve işlemlerin temelinde akıl yürütme vardır ve o da olası bütün faktörleri ele alarak akılcı düşünme sürecidir (Umay \& Kaf, 2005). Matematiği akıl yürütmelerle, keşfederek öğrenen öğrenciler, mantıklı ve anlamlı öğrenme sürecinde yaratabildiklerini görürler (Umay \& Kaf, 2005). Yaşamın anlamlı bir biçimde sürdürülebilmesi için problemlere uygun çözüm üretilmesi elzemdir (Alkan \& Güzel, 2005). Bir problemin çözümünde geçen belli başlı düşünme yolları ve muhakeme süreçleri yüksek matematik konularının öğretim ve öğrenilmesi içinde ayrıca bir önem taşımaktadır (Dreyfus, 1991; Delice \& Sevimli, 2012). Öğrencilerin problemleri çözerken kullandıkları gösterimler, bizim onların nasıl düşündüklerini ve akıl yürüttüklerini anlamamızı sağlayabilmektedir. Örneğin, bazı öğrenciler problemleri sözel ifadelere indirgerken, bazıları uzamsal şekiller üzerinde durmaktadır (Umay \& Kaf, 2005). Araştırmalar, öğrencilerin birbirlerinden farklı düşünme biçimlerine, akıl yürütme tarzlarına sahip olduğunu göstermektedir. Analitik, bütünsel (holistic), pratik, yaratıcı gibi çeşitli biçimlerde akıl yürütenler için kendi tarzlarına uygun öğrenme ortamların düşüncelerini daha kolay yapılandırabilmeleri için elzemdir (Umay \& Kaf, 2005).

Matematiksel düşünme; bilişsel ve sosyal öğrenmeler ile ilerletilebilen bir yapıda olmalıdır. Bunun için ise, uygun öğrenme ortamı ve bu ortamda düşünce üretimine katkı sağlayabilecek farklı yaklaşımlarının sergilenmesi önem kazanmaktadır. Sorgulayan ve düşündüğünü rahatça söyleyebilen bireyler ve özellikle bunu bir de problem çözme süreçlerine ekleyebilirlerse süreç daha faydalı olacaktır. $\mathrm{Bu}$ bağlamda öğrencilerin matematiksel düşünme becerilerini geliştirecek, farklı öğrenme yaklaşımlarını kullanan öğrenme ortamlarının oluşturulması önem kazanmaktadır (Bukova, 2008). Bir matematik probleminin, farklı öğrenciler tarafından, farklı stratejilerle çözülmesi süreci beklenilen ve hatta özellikle istenilen bir durum olmalıdır (Lowrie \& Kay, 2001; aktaran Delice \& Sevimli, 2012).

MEB (2017) müfredatı öğrencinin potansiyelini mümkün olduğu ölçüde geliştirmeye dikkat çekmektedir. Bunun için bilgi ve becerilerin kazandırılması esas alınmaktadır. Öğrencinin bilişsel stili ve görsel Okuryazarlığı potansiyeli hakkında bilgi verirken, matematik başarısı da bilgi, beceri ve anlayışını ortaya koymaktadır. İlkokul 2.sınıftan itibaren simetri kavramıyla uzamsal yönün gelişimine vurgu yapılmaktadır. Kazandırılması hedeflenen beceriler arasında tablo, resim ve grafik şeklinde görsel olarak sunulan bilgiyi okuyabilme, yorumlayabilme, değerlendirebilme, kullanabilme ve yeni görsel durumlar oluşturma becerileri oldukça ön plandadır (MEB, 2017). Literatürde bu beceriler görsel okuryazarlığı ifade eder (Heinich, Molenda, Russell \& Smaldino, 1996). Öğrenci, hedeflenen bu kazanımlara ulaşırken zihinsel olarak öznel bir yol izler. Bu yol, öğrencinin bilişsel stilini ifade eder ve bu stil, kişiden kişiye değişebilir. Örneğin, bir öğrenci bir kavram ya da bilgiyi öğrenirken, o bilgi ya da kavramı içinde bulunduğu bağlama bağlı olarak veya bu bağlamdan bağımsız olarak değerlendirip özümseyebilir. Yapılan çalışmalar takip edilen bu stratejilerin bireyde görsel ya da içsel olup olmamasına göre farklılaştığını ortaya koymuş ve içsel referansı tercih eden bireyler "alan bağımsız", görsel referansa yönelen bireyler ise "alan bağımlı" olarak nitelendirilmiştir (Goodenough; Aktaran Somyürek \& Yalın, 2007). Bu durum, öğrencinin zihinsel aktiviteleri esnasında kullandığı bilişsel stili yansıtmaktadır.

\section{Bilişsel stil}

Öğrencilerin akademik başarılarını nelerin etkilediğini anlamak amacıyla eğitimle ilişkili pek çok değişken incelenmiş ve bu değişkenler çeşitli araştırmaların konusunu oluşturmuş̧tur. Bu değişkenlerden birisi olan bilişsel sitiller son yıllarda öğrenciler arasındaki akademik başarı farklılıklarını açıklamak 
amacıyla kullanılan ve bu konuda yüksek beklentiler oluşturan önemli bir etkendir. Bilişsel stiller öğrenci başarılarını anlamlandırmaya yardımcı olmaktadır (Çakan, 2005).

Bilişsel süreçler, çevreden edinilen bilgiler, görsel ve sözel olarak kodlanarak bellekte saklanmaktadır. Bilișsel stratejiler, saklanan bilginin daha mukavemetli ve daha hızlı hatırlanabilmesini amaçlamaktadır. Görsel okuryazarlığı destekleyen ve altyapısını oluşturan birden fazla bilişsel öğrenme kuramı vardır. En önemlilerinden biri 20. Yüzyılın hemen başlarında Max Wertheimer tarafından temeli atılmış, Wolfgang Köhler ve Kurt Koffka'nın ilkelerine geliştirdiği Gestalt kuramıdır. Gestalt "her görünende, tek tek her parçanın birbirini etkilediği ve kendisi, parçalarının toplamından daha çok olan örgütlü bir bütün" olarak tanımlanmaktadır. Bu bağlamda parça parça ifadelerin, bilişsel olarak örgütlenmesi anlam ifade edecektir. Hatta parçaların etkileşimi bütünden daha fazla olacaktır.

Bilişsel stil bireylerin bilgiyi alma, organize etme, kullanma ve saklamada tercih ettiği yöntemleri ifade etmek amaciyla kullanılan bir kavramdır (Wapner ve Demick 1991; Witkin ve ark., 1977, aktaran Çakan, 2005). Bilişsel stil terimi bilgiyi işleme ve öğrenme ortamına aktarma sürecinde kullanılan stratejilerdeki bireysel farklılıkları tanımlamada ve açıklamada kullanılır (Riding \& Rayner, 1998). Bilişsel stili bireyin sorun çözmede, algılamada ve hatırlamada kullandığı yöntem, tutum ve biçim şeklinde tanımlayabiliriz. Bilişsel stiller, günlük yaşamda kazanılan basit alışkanlıklardan ve çevreyle elde edilen öğrenme stratejilerinden önemli ayrllıklar gösterir. Çünkü bilişsel stiller yavaş yavaş, deneyimlerle şekillenen birer kişilik özelliğidir (Kalyan-Masih, 1985). Bilişsel stil bireylerin nasıl öğrendiğii, algıladığı̆, düşündüğü ve problem çözdüğü ile ilgidir (Simpson, Portis \& Wieseman, 1994).

Bilişsel stilin iki kutuplu olma özelliği (alan bağımlı-alan bağımsız) bilişsel stilin "bireysel fark" değişkeni olmasını belirlediğinden en temel özelliktir. Yani bilişsel stil iki farklı biçimde bilgi işleme yöntemini temsil eder. Bu iki kavram arasındaki fark bilişsel stilin, "bireylerin deneyimleri farklı biçimlerde düzenleyerek anlam, değer, beceri ve strateji oluşturması" olarak, buna karşın öğrenme stilini, "anlam, değer, beceri ve stratejilerin bireylere özgü, tutarlı biçimde değiştirilmesi" olarak tanımlanmıştır (Akar, 2007).

\section{Görsel matematik okuryazarlı̆g}

Okuryazarlığın, farklı tanımları mevcuttur; Reinking (1994) "alfabe ile yazılı metinleri okuyabilme ve yazabilme" olarak tanımlarken National Research Council (NRC, 1989) öğrencilerin okuma-yazma ile ilgili faaliyetlerinin yanında sayısal, mantık ve matematiksel işlemlerin de farkında olunması demiştir. Görsel ve matematik okuryazarlığı gibi diğer okuryazarlıkların, genel okuryazarlığın bir alternatifi olmadığı ancak bir parçası veya destekleyicisi olduğu unutulmamalıdır (Chauvin, 2003; Reinking, McKenna, Labbo \& Kieffer,1998; Sims, O'Leary, Cook \& Butland, 2002). Bu okuryazarlıklara günlük yaşamda duyulan ihtiyaçtan dolayı, "okuryazarlık" kavramı birçok ülkelerin eğitim sistemlerinde temel amaçlarından biri olmuştur. Bu durum "günlük hayatta karşılaşılan problemlerin çözümünde matematiksel bilgiyi, düşünceyi ve karar verme süreçlerini kullanabilme becerisi” (OECD, 2006) şeklinde tanımlanan "Matematik Okuryazarlığı (MOY)" için de geçerlidir. MOY yetisine sahip olabilmek çeşitli seviyelerde matematikle ilgili temel yeterlik ve becerileri gerekmektedir. Bunlar; matematiksel işlemlerin gerçekleştirilmesi, matematiksel düşünme ve kavrama, matematiksel içerikle ilgili bilgi sahibi olma ve bu içerikle uygulamalar yapma becerileri gibi beceri ve yeterliklerdir.

Uluslararası Öğrenci Değerlendirme Programı (PISA), Ekonomik İşbirliği ve Kalkınma Örgütü (OECD)' nün üç yıllık aralıklarla düzenlenir ve 15 yaş grubundaki öğrencilerin günümüz bilgi toplumuyla ilgili bilgi ve becerileri kullanabilme yeteneğini ölçmeyi amaçlayan bir tarama çalışmasıdır. PISA projesinde üzerinde durulan "okuryazarlık" kavramı öğrencinin bilgi ve potansiyelini geliştirip, topluma daha etkili bir şekilde katılmasını ve katkıda bulunmasını sağlamak için yazılı kaynakları bulma, kullanma, kabul etme ve değerlendirmesi, matematiksel işlemlerin gerçekleştirilmesi, matematiksel düşünme ve kavrama gibi becerileri içerir (Akyüz \& Pala, 2010; EARGED, 2008, aktaran Bekdemir \& Duran, 2012). Buradan yola çıkarak birçok okuryazarlık çeşidinin tanımlandığ söylenebilir. $\mathrm{Bu}$ okuryazarlıklara günlük yaşamda duyulan ihtiyaçtan dolayı, "okuryazarlık" kavramı birçok ülkenin eğitim sistemine girmiş ve hatta eğitim sisteminin temel amaçlarından biri olmuştur (Bekdemir \& Duran, 2012). Bunlardan biri olan matematik okuryazarlı̆g 1 Akyüz ve Pala (2010)'ya göre matematik eğitimcilerinin dikkatini çeken önemli bir konudur. 
Günümüzde normal bir yaşam düzenini sürdürebilmek için görsel okuyup anlama, analiz ve değerlendirme, kısaca görsel okuryazar olma gerekliliği vardır. Görsel Okuryazarlık (GOY) tanımları arasında "tablo, resim ve grafik gösterimlerini okuyabilme, yorumlayabilme, değerlendirebilme, kullanabilme ve bunlarla yeni, yaratıcı görsel durumlar oluşturma becerisi" yer alabilir (Debes, 1968; Heinich, Molenda, Russell \& Smaldino, 1996; Hortin, 1980; Wileman, 1993, aktaran Bekdemir \& Duran, 2012). Bekdemir ve Duran (2012)'a göre tüm bunlardan yola çıkarak farklı okuryazarlıkların kesişmesinden doğan sanatsal matematik veya görsel matematik okuryazarlığı gibi yeni okuryazarlıkları, tanımlamak zorunlu hale gelmektedir.

21. yüzyılda hızla gelişen teknoloji görsel gereksinimi artırmaktadır. İnsanlar içinde yaşadığı çağa uyum sağlayabilmek ve bilginin yeni boyutlarına ayak uydurabilmek için görsel okuryazarlık kavramı ortaya çıkmıştır. Debes ve arkadaşları tarafından 1969 yılında “Uluslararası Görsel Okuryazarlık Derneği”ni (İnternational Visual Literacy Association) kurmuşlardır. Uluslararası Görsel Okuryazarlık Derneği (Visual Literacy Association- IVLA) (2006) Debes'in (1969-68,961) yaptığı görsel okuryazarlık. IVLA'a tarafından resmi görsel okuryazarlık tanımı olarak kabul görmüsstür. Buna göre; görsel okuryazarlığı bireyin görme esnasında sahip olduğu ve diğer duyusal deneyimleri ile geliştirdiği görme yeteneklerinin bir bütünü olarak görür. Gelişmiş ülkelerde 20. Yüzyılın ortalarına doğru kavramsallaşmaya başlasa da ilkel insanın günümüze kadar gelmeyi başaran mağara duvarlarındaki resimler, figürler görsel okuryazarllğın daha eski olduğunu göstermektedir. Antik Yunanda görsel okuryazarlık Platon ve Sokrates tarafından ilk kavramsal temelleri atılmış ve geometri öğretmek için görsel imgelerden yararlanmışlardır.

Görsel okuryazarlığı ülkemizde ilk olarak, “ görsel okuma ve görsel sunu” Türkçe dersi öğretim programında yer almıştır (MEB 2005). Daha sonra müfredat değişiklilerinde görsel okuryazarlı̆̆ın önemi giderek artmış ve en son yapılan müfredat değişikliğinde; MEB (2017) müfredatı öğrenci potansiyelinin mümkün olduğu ölçüde geliştirmeye dikkat çekmiştir. Bunun için de bilgi ve becerilerin kazandırılması esas alınır.

GOY diğer okuryazarlıklarla parça bütün ilişkisi içerisindedir (Kellner, 1998). Bu da; soyut düşünceleri canlı, inandırıcı ve bildik, anlaşı1ır yaparak farklı şekillerde aynı düşünceyi işleme yeteneği kazandırmasından dolayı MOY (matematik okur yazarlığı) ile daha güçlüdür (Feinstein \& Hagerty, 1994; İpek, 2003). Bu güçlü ilişki "Görsel Matematik Okuryazarlık (GMOY)" adında yeni bir okuryazarlık kavramını ortaya çıkarmaktadır.

Görsel okuryazarlık kavramını gelişimine katkıda bulunan.1982 yılına gelindiğinde görsel okuryazarlığın dilsel ve şekilse boyutuna iliş̧in kavramların ortaya çıkması için Braden ve Hortin tarafında haritalar yapmışlardır (Robertson 2007). Chomsky (1957,1964,1968,1975). Chomsky'nin dil üzerine yaptığ1 çalışmalarda görsel okuryazarlık için "evrensel gramer" kavramı kullanmıştır (aktaran Hortin,1994). Görsel okuryazarlık Debes'in kavramsallaştırmasından sonra eğitim-öğretim ortamlarında teorik ve uygulama olarak yoğun bir şekilde yer almaya başlamıştır (Box \& Cochenour, 1985). Bundan sonra Web tabanlı internet ağının yaygınlaşması dünyanın insanlarının büyük çoğunluğu görsel okuryazarlıkla karşı karşıya kalmıştır Avrupa da 1990 yıllarında eğitim müfredatına giren görsel okuryazarlık, 2000 y1llarında eğitimin temelini oluşturmuştur. Türkiye'de 2004 Milli Eğitim Müfredatına görsel okuryazarlık girmiş, 2017 yayınlanan yeni müfredatla daha önemli hale gelmiştir.

Literatür incelendiğinde görsel matematik okuryazarlı̆ğ ve matematik başarısı ilişkisini inceleyen çalışmalara rastlanmaktadır (Duran ve Bekdemir, 2013; Uysal ve Yenilmez, 2011; Özdemir, Duran ve Kaplan, 2016). Duran ve Bekdemir (2013), ilköğretim 7.sınıf öğrencileri ile yaptıkları çalışmada görsel matematik okuryazarlığı özyeterlik algısının, görsel matematik başarısının anlamlı bir yordayıcısı olup olmadığını belirlemeyi amaçlamışlardır. Görsel matematik okuryazarlığı özyeterlik algısının, görsel matematik başarısının anlamlı bir yordayıcısı olduğu sonucuna ulaşmışlardır. Öte yandan öğretmen adayları ile yapılan çalışmalar da vardır. Şefik \& Dost (2016), matematik öğretmen adaylarının matematik okuryazarlı̆g 1 hakkındaki görüş ve değerlendirmeleri incelemiştir. Öğretmen adaylarının matematik okuryazarlığı kavramının anlamına ilişkin sınırlı bilgiye sahip oldukları belirlemişlerdir. Stokes (2002), görsel okuryazarlıkla ilgili yaptığı literatür çalışmasında görsel okuryazarlık kavramının kapsamlı bir incelemesi için öğrenme stilleri ve demografik özellikler gibi diğer faktörler arasındaki olası 
ilişkilerin belirlenmesi gerektiği söylemiştir. Bu doğrultuda alan bağımlı/bağımsız bilişsel stillerin, görsel matematik okuryazarlığı ve matematik başarısı arasındaki ilişki önemli bir araştırma konusu haline gelmiştir. Ülkemizde alan bağımlı/bağımsız bilişsel stiller, görsel okuryazarlık ve matematik başarısını üzerine yapılan çalışmaların yeterli olmadığı düşünülmektedir.

\section{Simetri}

Geometri, günlük hayatta, bilimde, sanatta eleştirel düşünme ve problem çözme becerilerine katkıda bulunarak, öğrencilerin içinde yaşadıkları dünyayı daha yakından tanımalarına yardımcı olan bir yapıdadır (Baykul, 2002). Simetri; geometrinin, doğanın, şekillerin temel bir parçası (Knuchel, 2004) ve müfredatlarda önemli bir kavram olmasının yanı sıra estetik duygularını da geliştiren bir araçtır (Son, 2006; Olkun, 2006). Olasilık, cebir ve geometride problem çözmede de rutin ve rutin olmayan problemlerin çözümlerinde önemli bir rol oynar (Leikin, Berman \& Zaslavsky, 2000; Allendoefer, 1969; Köse, 2012). Matematiğin bütünü içerisinde birçok alanda yeri vardır. Hatta ileri düzeylerde grup teorisinde bile simetri kavramı yer almaktadır. Etkili kullanılabilmesi öğrencinin simetri kavramı ile ilk tanıştıkları ilköğretim yıllarında, kavramı iyi kazanmaları ve anlamlandırmaları ile mümkündür (Köse ve Özdaş, 2009). Simetri kavramının temeli eşlik kavramı birinci sınıfta başlar (MEB, 2009). Bu kadar anahtar bir kavramda yaşanılan sorunlar simetri konusunun yeterince anlaşılamadığını ortaya koymaktadır (Küchemann, 1980; Orton, 1999; Seidel, 1998'den aktaran Aksoy \& Beyazit, 2010; Son 2006). Son (2006) göstermiştir ki bazı öğretmenler paralelkenarın simetri ekseni olduğunu düşünmekte ve bazılarının da yansıma simetrisi ile ilgili yeterli kavramsal bilgiye sahip olmadığı, öğrenciye simetriyi öğretirken kavramsal bilgiden çok eşleme, katlama gibi yönteme odaklandıklarını belirtmiştir. Yine öğretmenler yansıma ile dönme simetrisini karıştırmakta, yansıma simetrisinin tanımlanması istendiğinde dönme simetrisini tanımladıkları ve bu yüzden de öğrencilerin bu kavramları yanlış öğrendikleri belirlenmiştir (Karadeniz, Baran, Bozkuş \& Gündüz, 2015).

Simetri kavramının 6-8. sınıflarda verilmesi öğrencinin geometrik düşüncesinin gelişmesi açısından önemlidir (Yavuzsoy-Köse, 2012). Yavuzsoy-Köse; araştırmalarında şeklin simetri doğrusu ile kesişmediği durumlarda simetriğinin yatay ve dikey doğruya göre belirlenmesinde başarılı oldukları diğer tüm durumlarda kavramsal hatalar yaptıkları gözlemlendi. Simetri konusu çocukların şekil kavramını oluşturmalarına yardım eder, problem çözmede rol oynar, estetik duygularının gelişmesine yardım eder (Hacısalihoğlu-Karadeniz, 2015). Öğrencilerin yaşadıkları zorlukların Van Hiele teorisindeki geometrik düşünme düzeylerinden görsel dönemde olmaları ile ve şekillerin bir bütün olarak görülmesi ile alakalı olabilir. (Hacisalihoğlu v.d., 2015). Hacısalihoğlu araştırması sonucu, muhtemel kavram yanılgılarının kaynağını teşhis etmek açısından faydalı olabilir. Yavuzsoy-Köse (2012) araştırmasında şeklin simetri doğrusu ile kesişmediği durumlarda simetriğinin yatay ve dikey doğruya göre belirlenmesinde başarılı oldukları diğer tüm durumlarda kavramsal hatalar yaptıklarını belirtmektedir. Simetri konusu çocukların şekil kavramını oluşturmalarına yardım eder, problem çözmede rol oynar, estetik duygularının gelişmesine yardım eder (Hacısalihoğlu-Karadeniz, vd.2015).Van de Walle, 2004; aktaran Hacısalihoğlu-Karadeniz, 2015). Öğrencilerin yaşadıkları zorlukların Van Hiele teorisindeki geometrik düşünme düzeylerinden görsel dönemde olmaları ile ve şekillerin bir bütün olarak görülmesi ile alakalı olabileceği söylemektedir. Bu durumlar, çalışmada simetri konusunun seçilmesinde etkili olmuştur. Simetri konusu çocukların şekil kavramını oluşturmalarına yardım eder, problem çözmede rol oynar, estetik duygularının gelişmesine yardım eder (Hacisalihoğlu-Karadeniz, vd.2015).

Simetri kavram erken yaşlardan itibaren bilişsel olarak algılanabilen bir kavramdır. Simetri Weyl (1952) tarafından iki şekilde tanımlanmıştır. Bunlar; estetik uyum güzelliği ifade eden tanım, bir bütün içindeki çeşitli parçaların uyum içinde bileşimini ifade etmek için kullanılır. İkinci tanım, daha geometri bir kavram olan; doğruya göre uzaklı̆̆ın ifade ederek tanımlanmıştır. Simetriyi uygulandığı şeklin özelliklerini değiştirmeyen bir dönüşüm olarak tanımlanmaktadır ( Leikin, Berman, Zaslavsky, 1997). Simetri öğrenciler tarafindan öğrenilmesinde önemli değişkenler vardır (Küchemann,1981: Lima,2006: Xistouri,2007: Köse, 2008). Bunlar; şeklin karmaşıklığı, simetri doğrusunu yönü, şeklin simetri doğrusu ile kesişmesi, şekildeki doğru parçasının simetri doğrusu ile açısı, kâğıt çeşididir. Bu değişkenler öğrencinin simetri kavramının öğrenmesinde çeşitli zorluklar yaşamasına neden olmaktadır. Simetri 
konusu çocukların şekil kavramını oluşturmalarına yardım eder, problem çözmede rol oynar ve estetik duygularının gelişmesine yardım eder (Hacısalihoğlu-Karadeniz, vd.2015, Van de Walle, 2004; aktaran Hacısalihoğlu-Karadeniz, 2015). Öğrencilerin yaşadıkları zorlukların Van Hiele teorisindeki geometrik düşünme düzeylerinden görsel dönem de olmaları ile ve şekillerin bir bütün olarak görülmesi ile alakalı olabilir (Çeziktürk-Kipel, 2015).

İlköğretim matematik öğretim programında simetri kavramı ilköğretim ilk kademede simetri modelinin eşlikle açıklanması, doğruya göre simetri şekillerinin çizilmesi simetriye ilişkin temel kazanımlardır. İlköğretim ikinci kademesinde simetri, dönüşüm geometrisi başlı̆g 1 altında yer almaktadır. 7. Sınıf kazanım yansımanın açıklanması, 8.sınıf kazanımı koordinat düzleminde bir çokgenin eksenlerden birine göre yansıma, orjin etrafında dönme altında görüntülerini belirleyerek çizer. Simetri kavramının 6-8. sınıflarda verilmesi öğrencinin geometrik düşüncesinin gelişmesi açısından önemlidir (Yavuzsoy-Köse, 2012).

İlkokul 2. sınıftan itibaren simetri kavramı bazında uzamsal yönün gelişimine önem verilmektedir. Kazandırılması istenen beceriler; tablo, resim ve grafik şeklinde görüntülü olarak sunulan bilgiyi okuyabilme, yorumlayabilme, değerlendirebilme, kullanabilme ve yeni görsel durumlar oluşturabilme sayılabilir (MEB, 2017). Literatür ise bu becerilere matematik görsel okuryazarlığı ismini vermektedir (Heinich, Molenda, Russell,\& Smaldino, 1996). Bu kazanımlara ulaşmak bilişsel olarak öznel bir yol ister. Bu da bilişsel stil olarak adlandırılabilir. Bir kavram ya da bilgi öğrenilirken, o bilgi ya da kavramı içinde bulunduğu bağlama bağlı olarak veya bu bağlamdan bağımsız olarak değerlendirmek içsel referans1 tercih etmek veya etmemek olarak yorumlanabilir ki bu da alandan bağımsız veya bağımlı olmak olarak açıklanır (Goodenough; Aktaran, Somyürek \& Yalın, 2007). Bu araştırmada matematik öğretmen adaylarında simetri konusunda bilişsel stil, görsel matematik okuryazarlığ 1 ve matematik başarısı arasındaki olası ilişkiler incelenmesi amaçlanmıştır. Bilişsel stil alana bağımlılık ve alandan bağımsızlık boyutları bazında düşünülmüştür.

\section{YÖNTEM}

Bu çalışmada amaç, matematik öğretmen adaylarının simetri konusundaki kavram yanılgıları, zorlukları kadar üstün oldukları yanları keşfetmek ve bu yanların görsel matematik okuryazarlığ 1 ve bilişsel stilleri arasında varsa ilişkiyi ortaya çıkarmaktır. Simetrinin görsel bir konu olması sebebi ile görsel okuryazarlığı yüksek öğrencilerin bu konuda başarılı olması beklenmektedir. Simetri aynı zamanda referans alınan noktalara göre değiştiğinden (Çeziktürk-Kipel, 2015), alana bağımlılıkla bağdaşacağı düşünülmektedir.

$\mathrm{Bu}$ çalışmada 'Matematik öğretmen adaylarının simetri konusundaki matematik başarı puanları, görsel matematik okuryazarlığı durumu ve bilişsel stilleri arasında anlamlı bir ilişki var mıdır?’ sorusuna cevap aranmışıır. Araştırmanın alt soruları,

1. Matematik öğretmen adaylarının simetri konusundaki matematik başarı puanları ile görsel matematik okuryazarlığı arasında anlamlı bir ilişki var mıdır?

2. Matematik öğretmen adaylarının simetri konusundaki matematik başarı puanları ile bilişsel stilleri arasında anlamlı bir ilişki var mıdır?

3. Matematik öğretmen adaylarının görsel matematik okuryazarlığı durumu ile bilişsel stilleri arasında anlamlı bir ilişki var mıdır?

4. Matematik öğretmen adaylarının simetri konusundaki kavram yanılgıları nelerdir?

5. Matematik öğretmen adayları simetri konusunda nerelerde zorluk çekmektedirler? Sorularından oluşmaktadır.

\section{Araştırmanın Modeli/ Deseni}

Araştırma matematik öğretmen adaylarının simetri konusundaki başarıları, görsel matematik okuryazarlığı ve bilişsel stilleri arasındaki ilişkiyi ortaya çıkarmayı amaçladığından nicel araştırma yöntemi kullanılmıştır. Araştırma deseni olarak üç değişkenin birbirleriyle olan ilişkileri incelendiğinden 
ilişkisel tarama modellerinden korelasyonel uygulanmıştır. Korelasyonel araştırma modelinde, değişkenler arasındaki ilişkiyi açıklama ve sonuçları tahmin etme fırsatı sunmaktadır (Tekbıyık, 2015).

\section{Örneklem}

Araştırmanın örneklemini, İstanbul'da bir devlet üniversitesinin 4. sınıfinda öğrenim görmekte olan ve Öğrenme Stilleri dersini alan 31 matematik öğretmeni adayı oluşturmaktadır. Örneklemi tespit ederken seçkili örneklem alma yollarından biri olan uygun örnekleme yolu tercih edilmiştir. Uygun örneklemede araştırmacı için elverişlilik önem kazanmakta ve grup bu şekilde belirlenmekte ve araştırma verileri o gruptan toplamaktadır (Büyüköztürk vd. 2011). Matematik öğretmen adaylarının simetri konusundaki kavram yanılgıları, zorlukları kadar üstün oldukları yanları keşfetmek ve bu yanların görsel matematik okuryazarlığı ve bilişsel stilleri arasında varsa ilişkiyi ortaya çıkarmanın amaçlandığı bu çalışmada ilköğretim matematik öğretmen adaylarıyla çalışılmıştır.

\section{Verilerin Toplanması/Süreç}

Veri toplamak amacıyla öğretmen adaylarına GEFT (Gizlenmiş Şekiller Grup Testi), Görsel Matematik Okuryazarlığı Testi ve Simetri Başarı Testi olmak üzere 3 test uygulanmıştır. Literatürde pek incelenmediği için ve diğer konulara göre daha fazla görsel içeriği olduğu için simetri konusu seçilmiş ve iki gün bilişsel stillere, bir gün diğer testlere ayrılmıştır. Matematik Aday öğretmenlerine sınav döneminde aldıkları dersin testine ek olarak bu testler verilmiş ve ölçüm yapılmıştır.

\section{Alana bağımlılık/Alandan bağımsızlığı ölçen bilişsel stil testi (GEFT)}

Gizlenmiş Şekiller Grup Testi (GEFT), büyük ve karmaşık bir şeklin için gizlenmiş basit bir şekli bulmaya çalıştıkları bir bilişsel stil belirleme testidir. Yüksek not alan kişilerin alandan bağımsız oldukları, düşük not alanların da alana bağımlı olduklarına karar verilir. Öğrencilerden 10 dakika içinde örnek sayfalar (ilk 7 şekil alıştırma amaçlı verilmiştir) dışında 18 soru içindeki basit şekilleri bulmaları istenir. Witkin, Oltman, Raskin \& Karp tarafindan 1971 yılında geliştirilmiş GEFT testi 3 bölüm ve toplamda 25 sorudan oluşmaktadır. Testte içlerinde basit bir şeklin olduğu karmaşık şekiller verilmektedir. İlk bölümde 7, ikinci ve üçüncü bölümde 9 soru bulunmaktadır. Katılımcılara ilk bölüm için 2, diğer iki bölüm için 5er dakika olmak üzere toplamda 12 dakika süre verilmekte ve soru içindeki gizlenmiş basit şekilleri bulmaları istenmektedir. İlk bölüm alıştırma niteliği taşımakta ve puanlamaya dâhil edilmemektedir. İkinci ve üçüncü bölümdeki 18 soru her birinin doğru yanıtı 1 , yanlış yanıtı 0 olacak şekilde puanlanmaktadır. Buna göre sonuçlar 0-18 arasında değişmekte ve aritmetik ortalamadan yüksek alanların alandan bağımsız bilişsel stile, düşük alanların ise alana bağımlı bilişsel stile sahip oldukları düşünülmektedir.

\section{Görsel Matematik Okuryazarlık Ölçeği}

Görsel matematik okuryazarlık ölçeği (Ek 2), görsel matematik okuryazarlı̆̆ı ile ilgili öz-yeterlilik algılarını doğrudan ve en kolay şekilde belirlenmesi bakımından 5'li Likert tipi ve 38 maddeden oluşmaktadır. 2012 tarihinde Duran ve Bekdemir tarafından geliştirilmiştir. 36 madde olumlu 2 madde olumsuzdur. En düşük puan 37, en yüksek puan 185tir. Olumlu maddeler, "hiçbir zaman" seçeneğinden "her zaman" seçeneğine yani 1'den 5'e; olumsuz maddeler ise "hiçbir zaman" seçeneğinden "her zaman" seçeneğine yani 5'den 1'e doğru (ters olarak) puanlanmıştır.15-25 dakika arası süren sınavda yüksek puan alanların görsel matematik okuryazarlığının yüksek olduğu düşünülmektedir. Buna göre ölçekteki her madde "hiçbir zaman", "nadiren", "bazen", "sık sık " ve "her zaman" şeklinde derecelendirilmiştir. Simetri konusuyla yakından alakalı olduğu düşünülen örnek ve ilişkili maddeler şunlardır:

•Aynı düzlemdeki iki doğrunun birbirine göre durumlarını gösterebilirim.

- Geometrik bir şekli parçalayarak yeni geometrik şekiller elde edebilirim.

-Geometrik şekilleri kenar özelliklerine göre sınıflandırabilirim.

•Cisimlerin döndürülmesini anlamda zorluk çekebilirim.

•Şekilleri verilmiş bilgileri daha kolay yorumlayabilirim. 


\section{Veri Toplama Araçları (Simetri Başarı Testi)}

Araştırmacılar tarafından literatüre dayanarak hazırlanan Matematik Başarı Testi çoktan seçmeli ve açık uçlu 12 maddeden oluşmaktadır (Ek1). Dokuz uzmanın görüşleri doğrultusunda simetri konusundaki çalışmalar ışığında geliştirilmiştir. Soruların bazıları alan yazında benzerleri bulunsa da (Atasay \& Erdoğan, 2017; Leikin, barman \& Zaslavsky, 1997; Yavuzsoy-Köse, 2012) sorular tamamen araştırmacılar tarafindan geliştirilmiştir. Simetri tanımı, basit şekillerde simetri ekseni, simetri eksenine göre yansıma, farklı kâğıt tiplerinde simetri çizilmesi ve 3 tane simetri konusunu işleyen problem, 1 tane de dilde simetri konusunu işleyen bir sorudan oluşan testin puanlamasında kısmi notlar da verilmiştir. Ayrıca her soru için doğru veya yanlış kodlaması da yapılarak soru bazlı bir veri alınması da amaçlanmıştır. Testin değerlendirilmesi uzmanların hazırladığı değerlendirme kriterlerine göre (simetri konusu alt başlıkları, literatürde bilinen kavram yanılgıları, zorluk düzeyleri ve tanımsal problemler) belirlenmiştir. Simetri tanımı, basit şekillerde simetri ekseni, simetri eksenine göre yansıma, farklı kâğıt tiplerinde simetri çizilmesi ve 3 tane simetri konusunu işleyen problemden oluşmaktadır.

\section{Verilerin Analizi}

Çalışmada elde edilen veriler SPSS programına girilerek her bir ölçme aracından elde edilen puanlarla ilgili ortalama, standart sapma ve yüzde hesapları gibi betimlemeli istatistikler belirlenmiştir. Ayrıca test sonuçları birbiri ile Pearson Product Moment korelasyon katsayıları ile hesaplanmıştır. İkili ikili yapılan ilişki testlerinde pozitif, negatif ve ilişkisiz olma durumu incelenerek anlamlı sonuçlar çıkarılmaya çalışılmıştır.

\section{BULGULAR}

Öğretmen adaylarının Gizlenmiş Şekiller Grup testi (GEFT), Görsel Matematik Okuryazarlı̆ğ testi ve Simetri Başarı testinden aldıkları puanların aritmetik ortalamaları ve standart sapma değerleri Tablo 1'de verilmiştir. Tabloda görüldüğü gibi 80 matematik öğretmen adayına uygulanan Görsel Matematik Okuryazarlığı Testi aritmetik ortalaması 161,15, GEFT testi aritmetik ortalaması 13,5 ve Simetri Başarı Testi ortalamas1 63,56 olarak bulunmuştur. Aday matematik öğretmenlerinin Görsel Matematik Okuryazarlığı üst seviyelerde çıkarken, GEFT eğiliminin alandan bağımsızlığa doğru kaydığı gözlemlenmiştir. Simetri başarı testinde de yaptıkları belli başlı hatalar ve kavram yanılgıları dışında genelde orta başarıda oldukları gözlemlenmiştir.

Tablo 1. Veri Toplama Araçlarından Elde Edilen Verilerin Betimsel İstatistik Sonuçları

\begin{tabular}{llllll}
\hline & N & Min & Max & Ort & Std \\
\hline Görsel & 80 & 114 & 185 & 161,15 & 14,04613 \\
Geft & 80 & 2 & 16 & 13,5 & 2,28368 \\
Simetri basari & 78 & 29 & 91 & 63,5641 & 12,30098 \\
\hline
\end{tabular}

Simetri başarı testinde öğrencilerin karşılaştı̆̆ zorluklar başlıklar halinde ayrıca ele alınmaktadır. $\mathrm{Bu}$ sayede en çok hatanın yapıldığı ve yanılgının bulunduğu alanlar tespit edilebilir.

\section{Simetri Tanımı}

Simetri başarı testinde (Ek-1) ilk soru simetri kavramının tanımını seçmeye yöneliktir. Katılımcıların ilk soruya cevapları Tablo 2'de verilmiştir. Simetri testinde birinci soruda simetri tanımı olarak düşünülebilir sorusuna en fazla verilen cevap katlama olmuştur en az verilen cevap fonksiyondur. Verilerin analizi sonrasında elde edilen bilgilere göre katlama, ayna ve yansıma seçenekleri simetri tanımı olarak en çok düşünülürken, fonksiyon ve hareket en az tercih edilen iki seçenek olmuştur. Bu cevaplardan katlama, dönüşüm ve yansıma uzman görüşlerine göre en doğru tanımlar olarak farklı kaynaklardan alınmıştır.

Tablo 2. Simetri Tanımı İçin Verilen Cevaplar

\begin{tabular}{lll}
\hline Tanım & Yüzdesi & Açık tanım \\
\hline Katlama & $\% 78,2$ & Katlama ile oluşan eşlik (yanlış cevap olarak- Atasay\& Erdoğan, \\
& 2017) \\
Ayna & $\%$ 64,1 & Ayna görüntüsü(yanlış cevap olarak)
\end{tabular}




\begin{tabular}{|c|c|c|}
\hline Selfie & $\% 26,9$ & Selfie çekme \\
\hline Dönüşüm & $\% 48,7$ & $\begin{array}{l}\text { Biçim ve ölçü koruyan dönüşüm(Aksoy \& Beyazıt, 2014, aktaran } \\
\text { Atasay \& Erdoğan, 2017; Leikin, Barman \& Zaslavskyu, 1997; alınt1 } \\
\text { Yavuzsoy-Köse, 2012) }\end{array}$ \\
\hline Yansima & $\% 75,6$ & $\begin{array}{l}\text { Bir doğruya uzaklık korunumlu yansıma(Grenier, 1988; aktaran } \\
\text { Yavuzsoy-Köse, 2012) }\end{array}$ \\
\hline Fonksiyon & $\% 15,4$ & Birebir fonksiyon \\
\hline Hareket & $\% 21,8$ & $\begin{array}{l}\text { Nesnenin onu aynı bırakan hareketi(Stewart, 2007, aktaran Atasay \& } \\
\text { Erdoğan, 2017) }\end{array}$ \\
\hline
\end{tabular}

\section{Simetri Eksenini Belirleme}

Dikkat çeken diğer bir nokta ise öğretmen adaylarının simetri eksenini belirlemede yaptıkları hatalardır. Başarı testinin ikinci sorusunda paralelkenar, çember, çeşitkenar üçgen ve ikizkenar yamuğun simetri eksenlerinin bulunması istenmiştir. Çemberin simetri eksenini \% 97,4, çeşitkenar üçgenin simetri merkezini \%89,7, yamuğun simetri merkezini \% 94,9 kişi doğru yanıtlarken paralelkenarda bu oran önemli derecede düşmüştür. Elde edilen verilere göre aday öğretmenlerin \% 71,8'i paralelkenarın simetri eksenini yanlış bulmuştur. Literatürde benzer sonuçları bulan çalışmalar bulunmaktadır (Köse \& Özdaş, 2009; Atasay \& Erdoğan, 2017, Hacisalihoğlu-Karadeniz, 2015). Bu durumun nedeni olarak paralelkenarın 2 eş parçaya ayrılabilmesi ancak bunun için 180 derecelik bir dönmeye ihtiyaç duyulduğu söylenebilir. Dönme simetrisi ile yansıma simetrisinin ayrımının yapılamaması aynı şekilde dikdörtgen ile paralelkenarın da birbirine karıştırılıyor olması bu sonucu çıkarmış olabilir. Simetri testindeki problemlere verilen doğru cevap yüzdeleri Tablo 3'te verilmiştir.

Tablo 3. Simetri Problemlerine Verilen Doğru Cevap Yüzdeleri

\begin{tabular}{llll}
\hline Saat problemi & Dönme simetrisi-I & Dönme simetrisi-II & 598 \\
\hline$\% 65,4$ doğru & $\% 64,1$ doğru & $\% 19,2$ doğru & - \\
\hline
\end{tabular}

\section{Simetri problemleri}

Hem dönmenin hem de yansımanın olduğu sorularda hata oranının çoğaldığı gözlemlenmiştir. Dönme simetrisi-II problemi böyle bir problemdir. Araştırmalar dönme simetrisinin yansıma simetrisine göre öğrenciler tarafından daha zor anlaşıldığını ortaya koymaktadır (Çeziktürk- Kipel, 2015; Atasay \& Erdoğan, 2017). Özellikle Atasay\& Erdoğan (2017) mandala şekillerindeki simetri eksenlerini bulmalarını istedikleri öğrencilerin şekli bölen dönme simetrisi eksenlerini uzatarak doğruya göre simetri ile karıştırdıkları ortaya çıkmıştır. Şekli noktalara bölerek simetriyi göstermede başarılı oldukları, ama şekli bütün olarak düşündüklerinde dönme simetrisi eksenini ve dönme açısını bulmada zorluk çekebildikleri gözlemlenmiştir. Atasay\& Erdoğan (2017), öğrencilerin dönme simetrisinin olduğu yerlerde yansıma simetrisini göremeyince simetri olmadığını düşündüklerini gözlemlemişlerdir.

\section{Dil}

Simetri problemlerindeki anlamaya dayalı sorularda öğretmen adaylarının \% 79,2 sinin doğru sonuca ulaştığı belirlenmiştir. Bu sonucu simetri problemlerindeki cevap yüzdesi ile birleştirirsek, dilin bir faktör olduğu kesindir ancak iki şekilde etki ettiği söylenebilir. Birincisi soruyu anlamada, ikincisi ise sorunun içindeki simetriyi anlamadadır. Örneğin saat probleminde (şekil1) simetriyi doğru anlamalarına rağmen soruda isteneni yanlış anladıkları için doğru sonuca ulaşamayanlar olduğu gibi, sorudaki iki aşamalı simetriyi yanlış çözenler de soruyu yapamamışlardır.

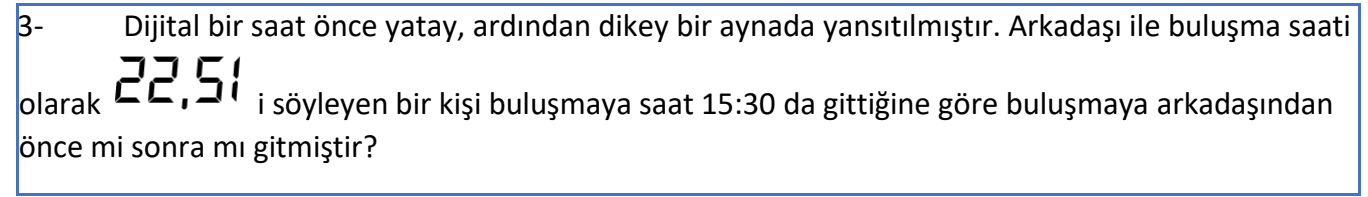

Şekil 1 Simetri testindeki saat sorusu 


\section{Simetri Ekseninin Konumu}

Testte bulunan 56 ve 7. sorular eksenlerin konumunun şekillerin simetriğini bulabilmedeki etkisini ölçme amaçlı hazırlanmıştır. Eksenlerin durumuna göre cevapların yüzdesi Tablo 4'te verilmiştir.

Tablo 4. Eksenlerin Durumuna Göre Cevapların Yüzdesi

\begin{tabular}{ll}
\hline Eksenlerin durumları & Yüzde \\
\hline Eksene değme & $\% 97,4$ doğru \\
Eğik eksen & $\% 82,1$ doğru \\
Eksenle kesişme & $\% 97,4$ doğru \\
\hline
\end{tabular}

Öğrenciler simetri ekseninin konumunu belirleme sorularında yüksek yüzdeyle doğru yanttlar vermişlerdir. Eksene değmede öğrencilerin \%97,4'ü doğru yanıt verirken, eğik eksen sorusunda öğrencilerin \%82,1'i doğru cevaplar verirken, \%17, 9'u yanlış cevaplar vermişlerdir. Son olarak Yavuzsoy-Köse'nin (2012) çalışmasının aksine öğrencilerin \%97,4'ü eksenle kesişmeye ilişkin sorulara doğru yanıt verirken, \%2,6’s1 yanlış cevaplar vermişlerdir. Çünkü o çalışmada bu tür problemlerin en büyük sorun yaratan problemler olduğu belirtilmiştir.

Bulduğumuz sonuçlar Köse \& Özdaş'ın (2009, aktaran Atasay \& Erdoğan, 2017) sonuçlarıyla paralellik göstermektedir. Literatürde eğik eksenin öğrenciler için zorluk oluşturduğu gözlemlenmiştir. Bizim çalışmamızda yanlış oranı \% 18 olarak belirlenmiştir. Yani diğerlerine göre; eksene değme veya eksenle kesişme durumlarına göre daha çok hata çıkmıştır ama bu oran yine de çok fazla olarak görülmemektedir.

\section{Arka Fonun Etkisi, Karmaşık Şekil ve 3D}

Testteki sorular incelendiğinde öğrencilerde arka fonun simetri almada etkili olup olmadığı anlaşılmaya çalışılmıştır. Veriler incelendiğinde öğrencilerin kareli kâğıtta simetri almada \% 6,4, noktalı kâğıtta \% 3,8 yanlış yapmışken düz kâğıtta bu oranın \%30,8 e yükseldiği görülmüştür. Atasay\& Erdoğan (2017) da düz kâğıdın simetriği bulmada işleri zorlaştırdığını söylemiştir. Küchemann (1981) kullanılan kâğıdın kareli olması öğrenciler açısından şekillerin doğruya göre simetriğinin alınmasından güçlü bir yardımcı olduğu vurgulamıştır Öğrenciler kendilerinden emin olmadıklarında da sorunun bu kısmını boş bırakmış olabileceği göz önüne alınmalıdır.

Diğer soruda karmaşık bir şeklin simetrisinin alınması istenmiş ve \%11,5 yanlış cevap verilmiştir. Atasay \& Erdoğan (2017) karmaşık mandala şekillerinin simetri bulma işini zorlaştırdığını söylemiştir. 3 boyutlu şeklin simetriğini bulmada ise \% 6,4 yanlış sonuca ulaşılmıştır. Aday öğretmenlerin aldıkları dersler sayesinde bu yönlerinin gelişmiş oldukları düşünülebilir.

\section{Korelasyon sonuçları}

Verilerin analizini yapmak için öncellikle verilerin normal dağılıp dağılmadığı belirlemek için SPSS'te normallik testleri yapılmıştır. Simetri başarı testi dışında diğer iki değişken normal dağılım göstermemiştir. Normalllik şartının sağlanmadığı değişkenler için değişkenin z-skoru hesaplanmış ve korelasyon testine bu yeni değişkenler sokulmuştur. Normallik şartı sağlandığı için (tablo 5) veriler arasındaki ilişki incelenebilir olarak düşünülmüştür. Görsel matematik okuryazarlığı, Geft ve Simetri testi sonuçları arasındaki korelasyon bulunarak Tablo 6 oluşturulmuştur.

Tablo 5. Normallik Testi Sonuçları

\begin{tabular}{lllllll}
\hline & \multicolumn{3}{l}{ Kolmogorov-Smirnov } & \multicolumn{5}{l}{ Shapiro-Wilk } \\
\hline & Stat & df & Sig. & Stat & df & Sig. \\
\hline Görsel & 0,125 & 78 & 0,004 & 0,933 & 78 & 0,000 \\
Geft & 0,235 & 78 & 0,000 & 0,744 & 78 & 0,000 \\
Simetri- & 0,084 & 78 & 0,200 & 0,986 & 78 & 0,549 \\
başarı & & & & & & \\
\hline
\end{tabular}


Tablo 6. Bilişsel Stil, Görsel Matematik Okuryazarlığı ve Matematik Başarısı Arasındaki Korelasyona Dair Sonuçlar

\begin{tabular}{lllll}
\hline & & Görsel & Geft & Simetri B.T. \\
\hline Görsel (z-score) & Pearson & 1 & 0,008 & 0,200 \\
& Sig(2-tailed) & & 0,945 & 0,079 \\
& N & & 80 & 78 \\
\hline Geft (z-score) & Pearson & 0,008 & 1 & $0,289^{*}$ \\
& Sig(2-tailed) & 0,945 & 80 & 0,010 \\
& N & 80 & & 78 \\
\hline Simetri-başar1 & Pearson & 0,200 & $0,289^{*}$ & 1 \\
& Sig(2-tailed) & 0,079 & 0,010 & 78 \\
& N & 78 & 78 & \\
\hline
\end{tabular}

Testlerin ikili ilişkilerini incelemek için SPSS programından korelasyonel hesaplamalar yapılmıştır. Sonuçlar incelendiğinde Gizlenmiş Şekiller Grup Testi ile Simetri Başarı Testinin arasındaki korelasyon katsayısının pozitif yönde daha yüksek olduğu, doğal olarak aralarındaki ilişkinin diğerlerine nazaran daha anlamlı olduğu görülmektedir (Tablo 3). Yine de bu ilişki \% 29 larda kalmıştır. Bu da oldukça düşük bir yüzdedir.

Simetri testi ile GEFT testi için $r=0,289 p=0,010$ ve Simetri testi ile görsel okuryazarlık testi için $r=0,200$ $\mathrm{p}=0,079$ sonuçları elde edilmiştir. Elde edilen sonuçlara göre simetri ve GEFT testi arasında pozitif yönde düşük bir ilişki vardır. Aynı zamanda simetri ile görsel okuryazarlık testi arasında da düşük bir ilişki vardır. Yani görsel okuryazarlığı yüksek öğrenciler simetri konusunda başarılıdır veya GEFT testinde yüksek puan alan öğrenciler simetri konusunda başarılır gibi düşünceler gerçeği yansıtmayabilir. Geft ile simetri başarı testi korelasyonuna gelince 0,05 seviyesinde birisinden yüksek alanın öbüründen de yüksek aldığı ve bunun tersinin de olduğu söylenebilir.

\section{TARTIŞMA VE SONUÇ}

Ortaögretim programında simetri konusu 11. sınıfta bulunmakta ve son konu olması itibari yetiştiremeyen öğretmenler tarafindan genelde üstü örtülü kalan bir konudur. Ortaokulda ise 8. sinıfta anlatılmakta ama kazanımlar içerisinde dönme simetrisi kavramı bulunmayıp şeklin bütününün döndürülmesinden çok koordinat sistemi üzerinde noktasal işlemler yapılmaktadır. Simetri konusunda alandan bağımsı bilişsel stile sahip öğrencilerin daha başarılı oldukları düşünüldüğünde alana bağımlı öğrencilerin de başarılı olması için bir şeyler yapılabilir. Farklı konularla bağlantıları kurulabilir, geometri, uzamsal beceriler, matematik ve sanat ile günlük hayat bağlantıları arttırılıp konunun daha somut hale gelmesi sağlanabilir.

$\mathrm{Bu}$ çalışma ile matematik başarısının görsel matematik okuryazarlığı altında simetri konusu, matematik öğretmenlerinin bilişsel sitilleri incelenmiştir. Matematik öğretmen adaylarına üç farklı test uygulanmış ve testlerin korelâsyonlarına bakılmıştır. Görsel okuryazarlık testi bir çeşit algı anketi, GEFT testi ve simetri testi ise sorulara doğru cevap vermek üzerine hazırlanmış testlerdir. Matematik öğretmen adaylarına son olarak simetri testi uygulanmıştır. Simetri testinden sonra görsel okuryazarlık testi uygulanmış olsaydı, matematik öğretmen adayları neyi bilip neyi bilmediklerini bu teste ifade edebilirlerdi. Görsel okuryazarlık testinin 18 maddesinin simetri testinin ve GEFT testinin sorularıyla alakalı olmadığı ortaya çıkması, korelasyon ilişkisinin olmadığından çıkarılabilir. Görsel okuryazarlık testi, şekilleri okuyabilme, tanıyabilme, ifade edebilme ile alakalı içeriğe sahiptir. Biz testimizde zorluk derecesi çok yüksek şekiller seçilmemiştir. Ancak zorluk derecesi yüksek şekiller muhteva etmesi durumunda sonuç ta değişebilirdi.

Simetri testi ile geft $(r=0,289 \mathrm{p}=0,010)$ simetri ile görsel okuryazarlık $(r=0,200 \mathrm{p}=0,079)$ sonuçları düşünüldüğ̈̈nde iki korelasyon katsayısının birbirine oldukça yakın olduğu görülmektedir. Araştırma daha büyük bir örneklem ile tekrarlandığında sonuçlar değişebilir. Ayrıca simetri yerine farklı bir konu seçilse sonucun da daha farklı olabileceği tahmin edilmektedir. 
$\mathrm{Bu}$ araştırmada simetri testi en son uygulanmıştır. Eğer öğretmen adaylarına önce simetri testi uygulanıp simetri kavramındaki eksiklerini fark etmeleri sağlansaydı görsel okuryazarlık anketine daha gerçekçi yanıtlar verebilirlerdi. Bu noktada öğrenciler üst bilişsel farkındalıklarının yeterince gelişmemiş olabilir ve kendileri de neyi bilip bilmediğinin farkında olmayabilirler.

Görülmüştür ki, son sınıf öğrencilerinin hâkim olması gereken simetri konusunda kavram yanılgıları ve yanlış bilgiler söz konusudur. Simetri tanımı olarak katlamada $\% 78,2$, aynada $\% 64,1$ yanlış oranı ve saat sorularındaki yanıtlar buna örnek olarak verilebilir. Aradaki anlamlı ilişki göz önüne alındığında, matematik öğretiminde simetri konusuna ağırlık verilmesi öğrencilerin gelişimi ve kavrayışlarına pozitif etki yapacaktır. Uygun zamanda yeterli eğitimi alamamış ögrenciler, son sınıf olsalar bile hâlâ, temel ve prensipsel hatalar yapabilmektedir. Bunun önüne geçmek için ilkokul ve lisedeki belli bölümlerde simetri eğitimindeki kalite artırılmalıdır.

Ayrıca Görsel Okuryazarlık Testi daha çok şekilleri okuyabilme, tanımlayabilme, ifade edebilme ile alakalıdır. Simetri testindeki şekiller ise basit düzeyde kalmıştır. Görsellerin zorluk derecesi değişse farklı sonuçlar elde edilebilir. Belki görsel okuryazarlık testi yerine uzamsal beceri testi verilebilirdi. Bir de simetri konusu yerine farklı bir topik seçilse sonuç ta daha farklı olabilirdi.

Öğrencilerin bakış açısını belirlemek, öğrenci merkezli eğitim programlarının geliştirilmesi, uygulaması ve değerlendirmesi için faydalı olabilir. Öz-yeterlik algısı ile başarı arasında yakın ilişki olduğundan (Pajares, 2001; Senemoğlu, 2009) öğrencilerin görsel matematik okuryazarllğıyla ilgili öz- yeterlik algılarının belirlenmesi matematik başarısının artırılmasına büyük katkı sağlayacaktır. Araştırmacıların bu konuda katkıda bulunması faydalı olabilir.

Araştırmada kullanılan testler için aday öğretmen öğrencilerin bilişsel stilleri, görsel matematik okuryazarlığıyla ilgili öz yeterlik algılarını bireysel veya grup olarak belirleyebilen, uygulanması ve cevaplanması kolay birer ölçek olduğu söylenebilir. Geçerlik ve güvenirlik detayları da üstte verilmiştir. $\mathrm{Bu}$ bağlamda bir değişiklik gözlemlenilmemiştir.

Araştırmada belirlenen kavram yanılgılarının üstüne gidilmeli ve öğrencilerin bu konuda tartışıp konuyu daha iyi anlamaları sağlanmalıdır. Aday öğretmenler de bu sorunların olması, ilerde öğretmen olduklarında kendi öğrencilerinde de benzer sorunlar çıkacağının temel bir göstergesidir. Araştırmanın belirlediği kavram yanılgıları (paralelkenarın simetri ekseninin olmadığı halde var denilmesi (Köse \& özdaş, 2009; Atasay \& Erdoğan, 2017; Hacısalihoğlu-Karadeniz, 2015), simetri tanımında ayna kavramından bahsedilmesi, dönme simetrisinde ayna simetrisine oranla daha fazla zorluk çekilmesi (Çeziktürk-Kipel, 2015; Atasay \& Erdoğan , 2017), dönme simetrisi ve ayna simetrisinin birlikte olduğu sorularda yüksek oranda zorluk çekilmesi, eğik simetri ekseninin işleri zorlaştırması (Yavuzsoy-Köse, 2012 kadar değil) ve simetri kavramını içeren problemlerde problemi anlamada gene büyük oranda simetri kavramının tanımında hem fikir olunmadığı için ve simetri sorularındaki düz arka fonun sorunun anlaşılmasında zorluk yaratması) literatürdeki diğer araştırmalarla paralellik göstermektedir. Simetri kavramı anlatılırken bu noktaların üzerinde önemle durulması lazımdır.

Bilgilendirme / Acknowledgement: Makalenin önceki sürümü UEYAK 1 kongresinde bildiri olarak sunulmuştur.

\section{KAYNAKÇA}

Akar, G.K. (2007). Conceptions of Between-ratios and within-ratios. Unpublished Doctoral Dissertation, Penn State University, State College, USA.

Aksoy, Y., \& Bayazit, İ. (2010). Simetri kavramının öğrenim ve öğretiminde karşılaşılan zorlukların analitik bir yaklaşımla incelenmesi. In. M.F. Özmantar \& E. Bingölbali (Eds.) Illkögretimde karşılaşılan matematiksel zorluklar ve çözüm önerileri, 187-215.

Akyüz, P., Pala, N., (2010). PISA 2003 Sonuçlarına göre öğrenci ve sınıf özelliklerinin matematik okuryazarlığının problem çözme becerilerine etkisi. ilköğretim Online, 9(2), 668- 678. 
Alkan, H., \& Güzel, E. B. (2005). Öğretmen adaylarında matematiksel düşünmenin gelişimi. Gazi Ĕ̈itim Fakültesi Dergisi, 25(3), 221-236

Allendoerfer, C. B. (1969). The dilemma in geometry. The Mathematics Teacher, 62(3), 165-169.

Alpan, G., (2008). Görsel okur-yazarlık ve öğretim teknolojisi. Yüzüncü Yıl Üniversitesi Eğitim Fakültesi Dergisi Aralık 2008, V,II, 74-102.

Arslan, S. \& Yıldız,C. (2010). 11. sınıf öğrencilerinin matematiksel düşünmenin aşamalarındaki yaşantılarından yansımalar. Eğitim ve Bilim, 35, 17-31

Atasay, M. \& Erdoğan, A. (2017). Matematik ile sanatın ilişkilendirilmesi: Mandala desenlerinin simetri öğretiminde kullanımı. Journal of Instructional Technologies \& TeacherEducation, 6, 2, 58-77.

Baykul, Y. (2002). İlköğretimde Matematik Öğretimi (6-8. Sinıflar için). Ankara: Pegem Yayıncıllk Bekdemir, M. \& Duran, M. (2012). İlköğretim öğrencileri için görsel matematik okuryazarlı̆̆ Özyeterlik alg1 ölçeği (GMOYÖAÖ)'nin geliştirilmesi. Ondokuz Mayls Üniversitesi Ĕ̈itim FakültesiDergisi, 31(1), 89-115.

Box ,C.A. \& Cochenour. J. (1998). Visual literacy: What do prospective teachers need to know? Visual literacy in life and learning, The 19th Annual Conference of the İnternational Visual Literacy Association. Published in Virginia.

Bukova-Güzel, E. (2008). Yapılandırmacı öğrenme yaklaşımının matematik öğretmen Adaylarının matematiksel düşünme süreçlerine olan etkisi. e-Journal of New World Sciences Academy, 3(4), 678-688.

Büyüköztürk, Ş. Çakmak, E.K., Akgün, Ö. E., Karadeniz, Ş. \& Demirel, F. (2011). Bilimsel araştırma yöntemleri. Ankara. Pegem Yayıncılık.

Chauvin, B.A. (2003). Visual or media literacy? Journal of Visual Literacy, 23(2), 119-28.

Çakan, M. (2005). Bilişssel stiller ile yabancı dil başarısı arasındaki ilişki: 8. sınıf Fransızca örneği. İlköğretim Online, 4(1).

Çeziktürk-Kipel, Ö. (2015). Simetri ve dönme eksenlerinin düzlem simetri gruplarının anlaşılmasındaki önemi. Bayburt Üniversitesi Eğitim Fakültesi Dergisi, X(I), 243-258.

Delice, A., \& Sevimli, E. (2012). Analiz Dersi Öğrencilerinin integral hacim hesabı problemlerindeki çözüm süreçlerinin düşünme yapısı farkl1lıkları bağlamında değerlendirilmesi. M.Ü. Atatürk Eğitim Fakültesi Eğitim Bilimleri, Dergisi, (36), 95-113.

Dreyfus, T. (1991). Advanced mathematical thinking processes. In D. Tall (Ed.), Advanced mathematical thinking (pp. 25-41). Dordrecht, The Netherlands: Kluwer.

Duran, M., Bekdemir, M. (2013). Görsel matematik okuryazarlığı özyeterlik algısıyla görsel matematik başarısının değerlendirilmesi. Pegem Eğitim ve Öğretim Dergisi, 3(3), 27-40.

Feinstein, H and Hagerty, R. (1994). Visual literacy in general education at the University of Cincinnati. Visual literacy in the digital Age: Selected readings from the annual conference of the International Visual Literacy Association (25th Rochester, New York, October 13-17, 1993,205-212.) (ERIC Document Reproduction Service No. ED 370 602).

Hacısalihoğlu- Karadeniz, M., Baran, T., Bozkuş, F., \& Gündüz, N. (2015). İlköğretim Matematik öğretmeni adaylarının yansıma simetrisi ile ilgili yaşadıkları zorluklar. Turkish Journal of Computer and Mathematics Education (TURCOMAT), 6(1), 117-138.

Heinich, R., Molenda, M., Russell,J., \& Smaldino, S.E. (1996). Instructional media and technologies for learning (5th Ed.). NewJersey: Prentice-Hall.

Hortin,J. A. (1980). Visual literacy and visual thinking. ERIC Number: ED214522 
Hortin, J. A. (1994). Theoretical Foundations of visual learning. In D. M. Moore \& F. M. Dwyer (Eds.). Visual literacy: A spectrum of visual learning (S. 5-29).

İpek, İ. (2003). Bilgisayar, görsel tasarım ve görsel öğrenme stratejileri. The Turkish Online Journal of Educational Technology-TOJET, 2(9), 68-76.

Kalyan-Masih, V. (1985). Cognitive performance and cognitive style. International Journal of Behavioral Development, 8(1), 39-54.

Kaplan, A., Öztürk, M. (2014). 2-8. sınıf öğrencilerinin simetri kavramını anlamaya yönelik düşünme yaklaşımlarının incelenmesi, İlköğretim Online, 13(4), 1502-1515.

Kellner, D. (1998). Multiple literacies and critical pedagogy in a multicultural society. Educational Theory, 48(1), 103-122.

Köse (2008). Illköğretim 5. Sinı öğrencilerinin dinamik geometri yazılımı Cabri Geometriyle Simetriyi anlamlandırmalarının belirlenmesi: Bir eylem araştırması, Yayımlanmamış doktora tezi, Anadolu Üniversitesi Eğitim Bilimleri Enstitüsü, Eskişehir.

Köse, N.F. (2012). İlköğretim öğrencilerinin doğruya göre simetri bilgileri. Hacettepe Üniversitesi Eğitim Fakültesi Dergisi, 42, 274-286.

Köse, N.F. ve Özdaş, A. (2009). İlköğretim 5. Sınıf öğrencileri geometrik şekillerdeki simetri doğrularını Cabri geometri yazılımı yardımıyla nasıl belirleniyorlar?. Illköğretim Online, 8(1), 159-175.

Knuchel, C. (2004). Teaching symmetry in the elementary curriculum. The Mathematics Enthusiast, 1(1), 3-13.

Kuchemann, D. (1980). Children's difficulties with single reflections and rotations. Mathematics in School, 9(2), 12-13.

Leikin, R., Berman, A. and Zaslavsky, O. (1997). Defining and understanding symmetry. In E. Pehkonen (Ed.). Proceedings of PME 21(3), 192-199.

Leikin, R., Berman, A., \& Zaslavsky, O. (2000). Applications of symmetry to problem solving. International Journal of Mathematical Education in Science and Technology, 31(6), 799-809.

Lima, I. (2006). De la modélisation de connaissances des élèves aux décisions didactiques des professeurs - Étude didactique dans le cas de la symétrie orthogonale, thèse de doctorat, Université Joseph Fourier, Grenoble I.

MEB. (2017). Matematik dersi öğretim programı ve kılavuzu (5-8.Sınıflar). Ankara: Milli Eğitim Basımevi.

MEB. (2015). Illkokul Matematik Dersi 1, 2, 3 ve 4. Sinıflar Öğretim Programı. 1 Haziran 2018 tarihinde http://ttkb.meb.gov.tr/www/ogretim-programlari/icerik/72 adresinden erişildi.

MEB. (2009). İlköğretim Matematik Dersi 1-5. Sınıflar Öğretim Programı. Ankara: Milli Eğitim Bakanlığı.1 Eylül 2011 tarihinde http://ttkb.meb.gov.tr adresinden erişildi.

NRC. (1989). A report to the nation of the future of mathematics education. Washington, DC: National Academy Press.

OECD. (2007). PISA 2006: Science competencies for tomorrow's world. I, OECD Publications.

Olkun (2006). Yeni öğretim programlarını inceleme ve değerlendirme 60 raporu: Matematik öğretim programı inceleme raporu. İlköğretim-Online, 96-111. 1 Ocak 2018 tarihinde http://ilkogretimonline.org.tr adresinden erişildi.

Özdemir, F., Duran, M., Kaplan, A. (2016). Ortaokul öğrencilerinin görsel matematik okuryazarlı̆̆1 özyeterlik algıları ile problem çözme beceri algılarının incelenmesi. Kuramsal Eğitimbilim Dergisi, 9(4), 532-554. 
Pajares, F. (2001). Toward a positive psychology of academic motivation. Journal of Educational Research, 95, 27-35.

Riding, R. \& Rainer, S. (1998). Cognitive styles and learning strategies: Understanding style differences in learning and behavior. London: David Fulton Publishers.

Reinking, D. (1994). Electronic literacy (Perspective Series No. 1-PS-N-07). Athens: GA and College Park, MD: The National Reading Research Center.

Reinking, D., McKenna, M. C., Labbo, L. D., \& Kieffer, R. D. (1998). Handbook of literacy And technology: Transformations in a post-typographic world. Mahwah, NJ: Erlbaum.

Robertson, M.S.M. (2007). Teaching visual literacy in the secondary English/ language arts classroom: An exploration of teachers' attitudes, understanding and application. 1 Temmuz 2018 tarihinde http://krex.k-state.edu/dspace/handle/2097/269 adresinden erişildi.

Senemoğlu, N. (2009). Gelişim öğrenme ve öğretim. Ankara: Pegem Akademi.

Simpson, F.M., Portis, S.C. \& Wieseman, R.A. (1994). Changing the cognitive style of Preprofessional students. Montgomery, AL: Auburn University Montgomery, (ERIC Document Reproduction Service No. ED 382 612).

Sims, E. O 'Leary, L., Cook , J.\& Butland, G.(2002). Visual literacy: What is it and do we need it to use learning Technologies effectively, Winds of Changing in the Sea of Learning, Proceedings of the 19th Annual Conference of the Australian Society for Computers in Tertiary Education (ASCILITE), Auckland, New Zealand, 8-11 December 2002

Somyürek, S. \& Yalın, H. İ. (2007). Bilgisayar destekli eğitim yazılımlarında kullanılan örgütleyicilerin alan bağımlı ve alan bağımsız öğrencilerin akademik başarılarına etkisi. Journal of Turkish Educational Sciences, 5(4),587-607.

Son, J. W. (2006). Investigating preservice teachers' understanding and strategies on a student's errors of reflective symmetry. Proceedings of the $30^{\text {th }}$ Conference of the International Group for the Psychology of Mathematics Education. Prague: Charles University, Faculty of Education, 5, $145-152$

Stokes, S. (2002). Visual literacy in teaching and learning: A literature perspective. Electronic Journal for Integration of technology in Education, 1(1), 10-19.

Şefik, Ö., Dost, Ş. (2016). Ortaöğretim matematik öğretmen adaylarının matematik okuryazarlı̆̆ı hakkındaki görüşleri. Necatibey Eğitim Fakültesi Elektronik Fen ve Matematik Eğitimi Dergisi, 10(2), 320-338.

Tekbıyık, A. (2015). Iliş̧sisel araştırma yöntemi. Kuramdan uygulamaya eğitimde bilimsel araştırma yöntemleri. (M. Metin Ed.). (2. Baskı). Ankara: Pegem Akademi Yayıncılık.

Tüzel, M.S. (2010). Görsel okuryazarlık. TÜBAR-XXVII-/2010-Bahar. 692-705.

Umay, A., \& Kaf, Y. (2005). Matematikte kusurlu akıl yürütme üzerine bir çalışma. Hacettepe Üniversitesi Eğitim Fakültesi Dergisi, (28), 188-195.

Uysal, E., Yenilmez, K. (2014). Sekizinci sınıf öğrencilerinin matematik okuryazarlığı düzeyi. Eskişehir Osmangazi Üniversitesi Sosyal Bilimler Dergisi, 12(2), 1-15.

Weyl, H. (1952). Symmetry. Princeton University Press, Princeton: New Jersey. Witkin, H.A. ,Oltman, P.K.,Raskin, E.\& Karp, S.A. (1971). Group Embedded Figures Test. Palo Alto, CA: Consulting Psychological Press.

Xistouri, X. (2007) Students' ability in solving line symmetry tasks. In D Pitta-Pantazi \& GN Philippou (Eds).Proceedings of the Fifth Congress of the European Society for Research in Mathematics Education. Lanarca, Cyprus: Department of Education, University of Cyprus. 
Yavuzsoy-Köse, N. (2012). İlköğretim öğrencilerinin doğruya göre simetri bilgileri. Hacettepe Üniversitesi Eğitim Fakültesi Dergisi, 42, 274-286.

Yavuzköy-Köse, N. \& Özdaş, A. (2009). İlköğretim 5. Sınıf öğrencileri geometrik şekillerdeki simetri doğrularını Cabri Geometri yazılımı yardımıyla nasıl belirliyorlar? İlköğretim Online, 8(1), 159-175.

\section{EK-1}

\section{Simetri Testi}

1- $\quad$ Aşağıdakilerden hangileri simetri tanımı olarak düşünülebilir?

-katlama ile oluşan eşlik,

-ayna görüntüsü

-selfie çekme

-biçim ve ölçü koruyan dönüşüm

-bir doğruya uzaklık korunumlu yansıma

-Birebir fonksiyon

-nesnenin onu aynı bırakan hareketi

2- Aşağıdaki şekillerin simetri eksenlerini çizin.

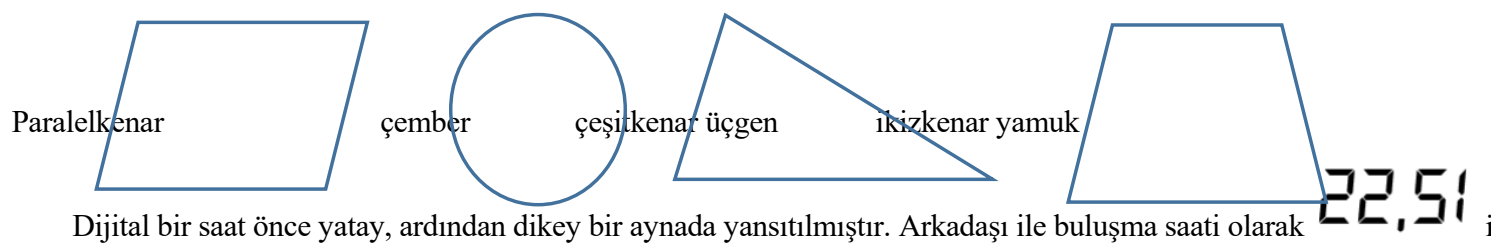
söyleyen bir kişi buluşmaya saat 15.30 da gittiğine göre buluşmaya arkadaşından önce mi sonra mı gitmiştir?

4- Dikey aynada simetriği alındığında aynı okunuşa sahip 3-4-5 harfli kelimelere örnekler verin. ATA,

5- $\quad$ Aşağıdaki şekillerde verilen şeklin simetri eksenine göre simetriğini çizin.

6-

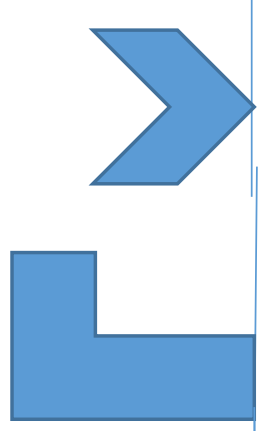

$7-$
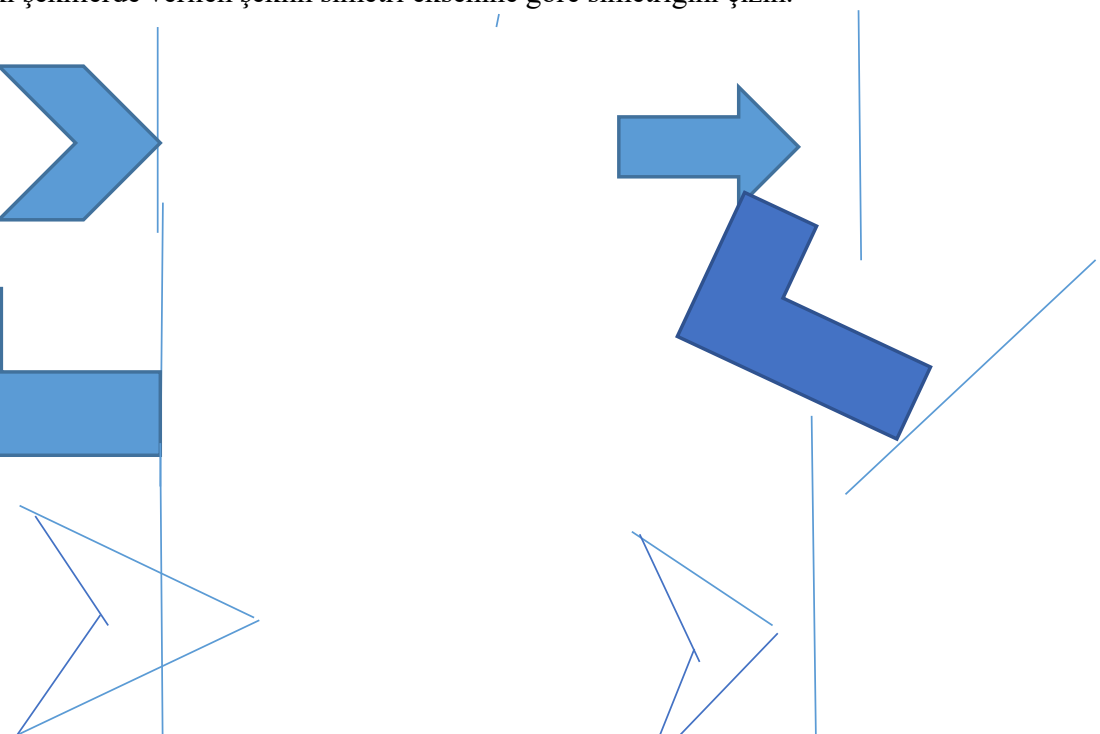

8- Sol üst köşesi A dan başlayarak isimlendirilen ABCDEF altıgeni saatyönünde 120 derece döndürülüyor. Döndürme sonras1 elde edilen altıgenin de dikine simetri eksenine göre simetriği alınıyor. Buna göre, ilk durumda $F$ noktasının bulunduğu köşseye, son durumda hangi nokta gelir? 
9- să̆ına simetriğini çizin

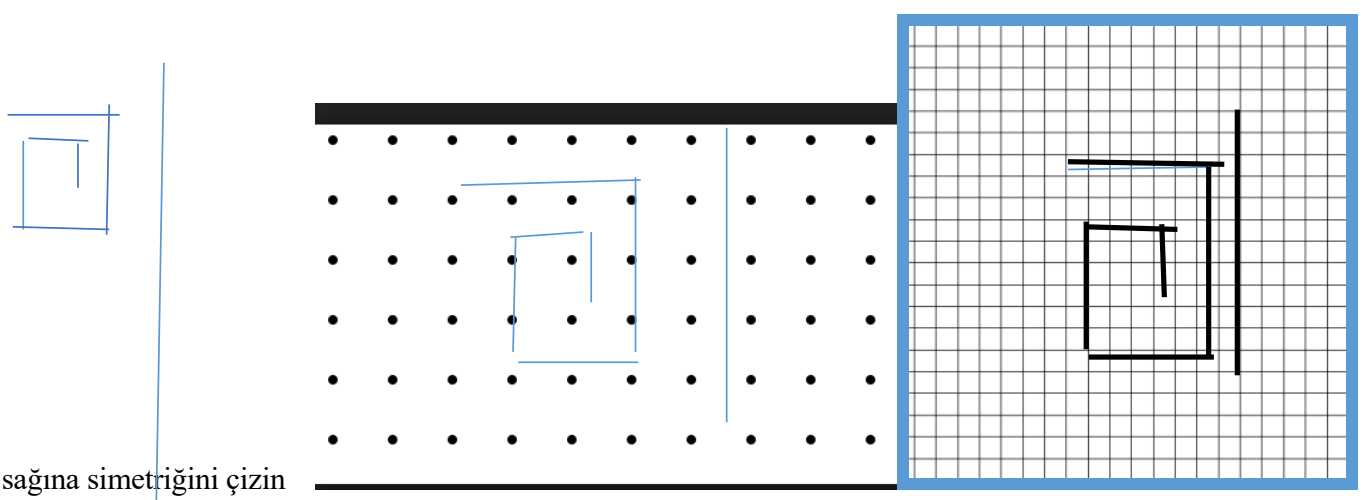

$10-$

$11-$

-
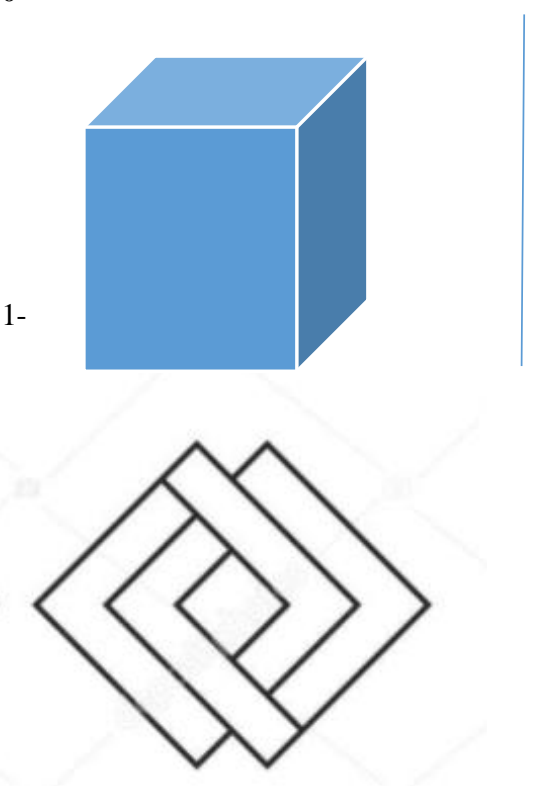

$12-$

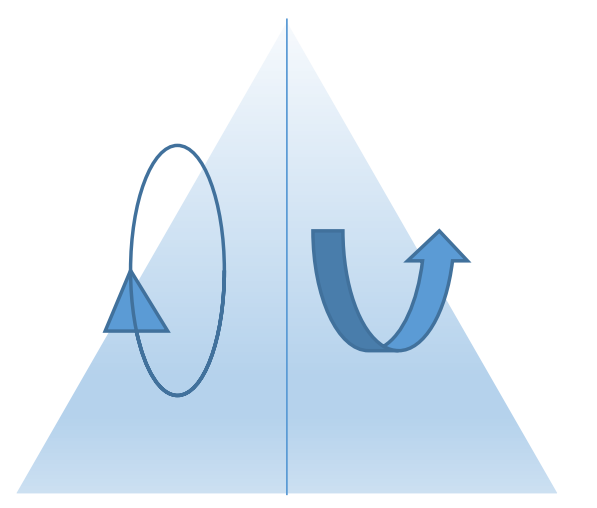

Üstteki eşkenar üçgeni ortadaki simetri ekseni boyunca kesiyoruz. Oluşan iki parça dönme simetrisi açısı kadar tepe noktası etrafında zıt yönlerde döndürülüyor. Taban köşeleri arasındaki mesafe hakkında hangileri söylenebilir?

1) Değişmez 2) yarıya iner 3) iki katına çıkar 4 )kök üç katına çıkar 5 ) sıfırlanır 